\title{
Prevalence and Outcome of Bleeding Gastro-esophageal Varices in Medical Intensive Care Unit at Zagazig University Hospitals, Egypt
}

\author{
Abdulla Abdelaziz and Monkez M. Yousif \\ Internal Medicine Department, Faculty of Medicine,Zagazig University, Egypt
}

Corresponding Author: Abdulla Abdelaziz

E mail: a.a.aziz2014@gmail.c om

Key words:prevalence; hematemsis; gastroesophageal varices;
Background and study aim:Ruptured gastro-esophageal varices (GEV) are the most severe and frequent cause of gastrointestinal bleeding in cirrhotic patients, leading to death in $5 \%$ to $8 \%$ of patients during the first 48 hours. Recently, the 6-week mortality rate has fallen from $34 \%$ to $20 \%$ due to the development of effective treatment strategies. This study was conducted to find out the prevalence of GEV as a cause of upper GI bleeding, a common medical emergency, and to find out the effect of other comorbidities and risk factors on the outcome.

Patients and Methods: This was an observational longitudinal prospective study. It included patients admitted to hematemesis subunit of medical ICU at Zagazig University Hospitals with endoscopic diagnosis of bleeding GEV in the period from May to September 2013. 448 patients were enrolled in this study. 374 patients of them were observed until stabilization and discharge (survived group) and 74 patients were observed throughout their stay in the medical ICU and unfortunately passed away (deceased group). All subjects of our study were subjected to complete history, full physical examination, routine investigations and upper GIT endoscopy.

Results: There was a significant positive correlation between hospital mortality and the age of the patients. The mean age of the deceased group was 59.44 ys \pm 5.89 compared to 47.9 ys \pm 9.93 of the survived group ( $\mathrm{p}$-value $=0.036$ ). Also the incidence of mortality in male sex was

\section{INTRODUCTION}

Ruptured gastroesophageal varices (GEV) are the most severe and frequent cause of gastrointestinal bleeding in cirrhotic patients leading to death in $5 \%$ to $8 \%$ of patients during the first 48 hours [1]. So, variceal bleeding $(\mathrm{VB})$ is a medical more than female sex (p-value $=0.005$ ). The stage of liver disease according to Child-Pough class, MELD Score (model of end stage liver disease), the presence of complication of cirrhosis and abnormal liver functions (high serum bilirubin, elevated ALT, low serum albumin and prolonged INR) were the most important factors contributing to mortality in intensive care patients suffering from GEV bleeding $(\mathrm{p}$-value $=0.002)$. The presence of co-morbid conditions (DM, COPD, renal failure), which were found in $20.3 \%$ of our patients, was associated with increased mortality ( $p$-value $=0.007$ ). Severity of bleeding, delayed endoscopic intervension, hemodynamic instability (at the time of endoscopy), all were associated with increased risk of mortality. high APACHE II score (Acute Physiology and Chronic Health Evaluation) is associated with marked increase in mortality.

Conclusion: Patients with variceal bleeding comprised a great burden to our medical ICU being about $13.7 \%$ of all admitted patients. The short term ICU mortality of these patients is $16.5 \%$. The multivariate regression analysis identified the APACHE II score, MELD score, severity of the bleeding attacks, time to endoscopic intervention. ALT level, advancing age, presence of co-morbidities and spontaneous bacterial peritonitis (SBP) were found to be independent risk factors. So, primary and secondary prevention as well as better adherence to current guidelines for management of such cases to minimize the mortality as much as possible are recommended.

emergency and its management should be undertaken in an intensive care setting by an experienced medical staff. High mortality rates were reported in older literature for patients with acute VB although there was a trend towards improved survival in those patients [2]. 
The current recommended haemostatic treatment of VB is to start a vasoactive drug on admission and associate endoscopic therapy at the time of diagnostic endoscopy [3].

Advances in pharmacological and endoscopic therapies have led to a decrease in mortality [4]. The 6-week mortality rate has fallen from $34 \%$ to $20 \%$ due to the development of effective treatment strategies [5]. Also, due to advances in medications and endoscopy, upper GI hemorrhage is now usually treated without surgery, Patients with upper GI hemorrhage often present with hematemsis, melena, or hematochezia if the hemorrhage is severe. The presentation of bleeding depends on the amount and location of hemorrhage [6].

The prevalence of variceal bleeding in a population of in-hospital patients is about $16 \%$. [7]. Another study stated that, in cirrhotic patients without varices at first endoscopy, the prevalence of new varices is 5-10\% [8]. Also according to Groszmann et al. [9] it was postulated that the varices are present in about $30-40 \%$ of compensated cirrhotic patients and in $60 \%$ of decompensated patients.

This study was planned for estimation of the prevalence of bleeding esophageal varices in medical intensive care unit with evaluation and analysis of clinical, biochemical and endoscopic features of involved patients. Also, assessment of prognostic scoring system in relation to patient outcome and study of the risk factors affecting the mortality in this group of patients.

\section{PATIENTS AND METHODS}

This study was carried out in the hematemesis subunit of medical intensive care unit of Internal Medicine Department, Faculty of Medicine, Zagazig University Hospitals in the period from May to September 2013.

The study was conducted on 448 subjects who were admitted because of bleeding due to ruptured GEV as diagnosed by Endoscopy. They were divided, according to survival, into 2 groups : survived group, which included 374 patients admitted and observed throughout their hospital stay and deceased group, which included 74 patients admitted and observed throughout their stay in the medical ICU and unfortunately passed away. The survived group included 245 males and 129 females with a mean age \pm SD of $47.9 \pm 9.93$ years. They were discharged after stabilization. The deceased group included 60 males and 14 females with a mean age \pm SD of $59.44 \pm 5.89$ years. This number was selected from a total number of 735 patients admitted to the ICU with a preliminary diagnosis of acute upper GIT bleeding.

Patients were excluded from the study if they were suffering from non variceal bleeding as diagnosed by upper GIT endoscopy, non endoscopized patients (dropped out cases), refusal of the patients or their relatives to participate in the study. All patients were submitted to full clinical assessment including history taking, physical examination, and the following investigations: complete blood picture, liver function tests, renal function tests, bleeding profile, random blood glucose level, arterial blood gases, ascitic fluid examination. Other investigations included : chest $\mathrm{x}$-rays, abdominal ultrasonography and upper GIT endoscopy. The liver condition was assessed using Child- Pugh class (A, B and C) and MELD score (Model of End stage liver Disease) The MELD score was calculated using the original formula without including the cause of liver disease [10].

MELD score $=(9.57 \times($ creatinine $\mathrm{mg} / \mathrm{dL})+3.78$ x (bilirubin $\mathrm{mg} / \mathrm{dL})+11.20 \mathrm{x}(\mathrm{INR})+6.43$ )

Pre-endoscopic evaluation to identify those patients who may be at risk of further bleeding or dying and those who would require blood transfusion or intervention to stop bleeding either endoscopic or surgical, we used Blatchford score (Glasgow-Blatchford Score ). The score was developed using a combination of clinical and laboratory Parameters (presentation with syncope or melaena, evidence of hepatic or cardiac disease, pulse and blood pressure, hemoglobin and urea) [11].

The score is calculated using the table below: 
Glasgow-Blatchford Score

\begin{tabular}{|c|c|}
\hline Admission risk marker & Score component value \\
\hline \multicolumn{2}{|l|}{ Blood Urea } \\
\hline$\geq 6 \cdot 5<8 \cdot 0$ & 2 \\
\hline$\geq 8 \cdot 0<10 \cdot 0$ & 3 \\
\hline$\geq 10 \cdot 0<25 \cdot 0$ & 4 \\
\hline$\geq 25$ & 6 \\
\hline \multicolumn{2}{|c|}{ Haemoglobin $(\mathrm{g} / \mathrm{L})$ for men } \\
\hline$\geq 12.0<13.0$ & 1 \\
\hline$\geq 10.0<12.0$ & 3 \\
\hline$<10.0$ & 6 \\
\hline \multicolumn{2}{|c|}{ Haemoglobin $(g / L)$ for women } \\
\hline$\geq 10.0<12.0$ & 1 \\
\hline$<10.0$ & 6 \\
\hline \multicolumn{2}{|c|}{ Systolic blood pressure (mm Hg) } \\
\hline $100-109$ & 1 \\
\hline $90-99$ & 2 \\
\hline$<90$ & 3 \\
\hline \multicolumn{2}{|l|}{ Other markers } \\
\hline Pulse $\geq 100$ (per min) & 1 \\
\hline
\end{tabular}

\begin{tabular}{|l|l|}
\hline Presentation with melaena & 1 \\
\hline Presentation with syncope & 2 \\
\hline Hepatic disease & 2 \\
\hline Cardiac failure & 2 \\
\hline
\end{tabular}

In the validation group, scores of 6 or more were associated with a greater than $50 \%$ risk of needing an intervention.

By using APACHE II scoring system [12], we evaluated the clinical state of our patients and assessed their mortality.

\section{Statistical Analysis:}

All data were coded, checked, entered and analyzed using SPSS software version 17.

\section{RESULTS}

Figure (1): Flow chart showing frequency distribution of the patients with upper gastrointestinal bleeding in medical ICU of Zagazig University Hospitals (period from May to September 2013).

817 patients were admitted to medical ICU of Zagazig University hospitals during study period with preliminary diagnosis of UGIB (24.9\% of total admission). $448(61 \%)$ of these patients (i.e. $13.7 \%$ of all ICU cases) confirmed to have variceal bleeding and this means the prevalence of variceal bleeding in medical ICU of Zagazig University Hospitals was $13.7 \%$.

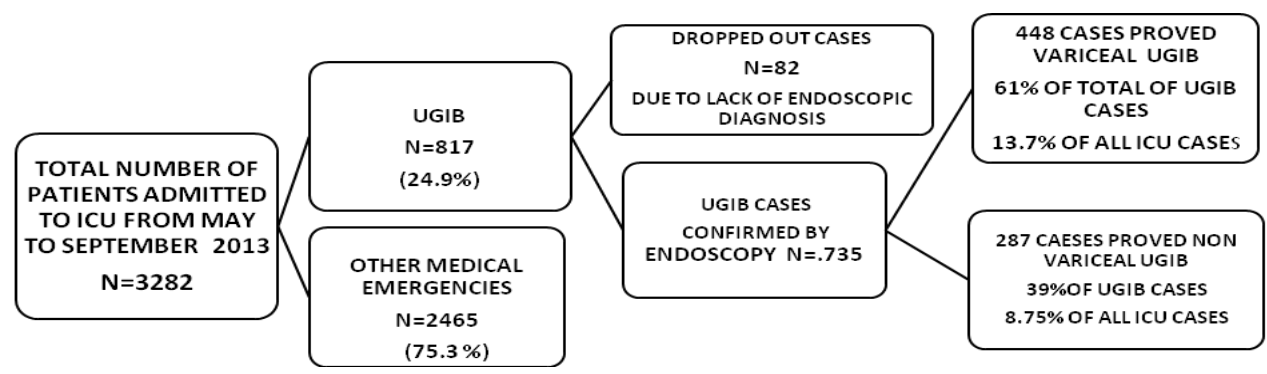


Table (1): Demographic and clinical characteristics of the study group ( $\mathrm{n}=448)$.

\begin{tabular}{|c|c|c|}
\hline & Number of the patients & Percentage\% \\
\hline Age (yrs) $\quad(\mathrm{X} \pm$ S.D $)$ & $52.3 \pm 9.42$ & \\
\hline $\begin{aligned} \text { Sex. M/F (\%) } & \text { - Male } \\
& \text { - Female }\end{aligned}$ & $\begin{array}{l}305 \\
143\end{array}$ & $\begin{array}{l}68.1 \% \\
31.9 \%\end{array}$ \\
\hline $\begin{aligned} \text { Smoking } & - \text { Smoker } \\
& \text {-Nonsmoker }\end{aligned}$ & $\begin{array}{l}104 \\
344\end{array}$ & $\begin{array}{l}23.2 \% \\
76.8 \%\end{array}$ \\
\hline $\begin{array}{ll}\text { NSAID use } & \text {-Used } \\
& \text {-Not used }\end{array}$ & $\begin{array}{l}110 \\
338\end{array}$ & $\begin{array}{l}24.6 \% \\
75.4 \%\end{array}$ \\
\hline $\begin{array}{ll}\text { Number of attacks } & -1^{\text {st. }} \\
& -2^{\text {nd. }} \\
& - \text { Recurrent } \\
\end{array}$ & $\begin{array}{c}86 \\
130 \\
232\end{array}$ & $\begin{array}{l}19.2 \% \\
29.0 \% \\
51.3 \% \\
\end{array}$ \\
\hline $\begin{array}{l}\text { Severity of the attack } \\
\text { - Mild } \\
\text {-Moderate } \\
\text {-Sever.(H.D unstable) }\end{array}$ & $\begin{array}{l}135 \\
182 \\
131\end{array}$ & $\begin{array}{l}30.1 \% \\
40.6 \% \\
29.2 \%\end{array}$ \\
\hline $\begin{array}{l}\text { History of CLD } \\
- \text { Known CLD. } \\
-1^{\text {st }} \text { discovered CLD } \\
\end{array}$ & $\begin{array}{c}378 \\
70 \\
\end{array}$ & $\begin{array}{l}84.4 \% \\
15.6 \% \\
\end{array}$ \\
\hline $\begin{array}{cl}\text { Child class } & \text { - Class A } \\
& \text {-Class B } \\
& \text {-Class C } \\
\end{array}$ & $\begin{array}{c}22 \\
188 \\
238 \\
\end{array}$ & $\begin{array}{l}4.9 \% \\
42.0 \% \\
53.1 \% \\
\end{array}$ \\
\hline $\begin{aligned} \text { Comorbidity: - Diabetic } \\
\text { - Heart failure } \\
\text { - COPD } \\
\text { - Renal failure. }\end{aligned}$ & $\begin{array}{l}40 \\
11 \\
21 \\
19\end{array}$ & $\begin{array}{l}8.9 \% \\
2.5 \% \\
4.7 \% \\
4.2 \%\end{array}$ \\
\hline $\begin{array}{l}\text { Complicated patient: } \\
\text { SBP } \\
\text { Hepatocellular carcinoma } \\
\text { Ascites } \\
\end{array}$ & $\begin{array}{c}118 \\
81 \\
386\end{array}$ & $\begin{array}{l}26.3 \% \\
18.1 \% \\
86.1 \% \\
\end{array}$ \\
\hline $\begin{array}{c}\text { Bleeding at Endoscopy } \\
\text { - Bleeder } \\
\text {-Non-bleeder } \\
\end{array}$ & $\begin{array}{l}105 \\
343\end{array}$ & $\begin{array}{l}23.4 \% \\
76.6 \%\end{array}$ \\
\hline $\begin{aligned} \text { Vasopressor use: } & \text { Used } \\
& \text { Not used }\end{aligned}$ & $\begin{array}{l}107 \\
341\end{array}$ & $\begin{array}{l}23.7 \% \\
76.3 \%\end{array}$ \\
\hline
\end{tabular}

*Demographic and clinical data of study population: $68.1 \%$ were males, $31.9 \%$ were females, $23.2 \%$ were smokers, $24.6 \%$ gave a history of recent NSAIDs intake, $19.2 \%$ presented for the $1^{\text {st }}$ time, $29 \%$ presented for $2^{\text {nd }}$ time while $51.3 \%$ gave a history of more than 2 attacks of bleeding. Regarding bleeding severity, mild, moderate and sever bleeding encountered in $30.1,40.6 \%$ and $29.2 \%$ respectively. Regarding liver disease severity $4.9 \%$ were Child (A), $42 \%$ were Child (B), while $53.1 \%$ were Child (C). $20.3 \%$ had co-morbid disease association. These patients presented with complication as spontaneous bacterial peritonitis (SBP) in (26.3\%), hepatocellular carcinoma (HCC) in $18.1 \%$ and ascites in (86.1\%). During Endoscopy active bleeding was encountered in $23.4 \%$ of the cases. 
Table (2): Univariate analysis of the data of the deceased group compared to survived group

\begin{tabular}{|c|c|c|c|c|c|c|c|}
\hline \multirow[b]{2}{*}{ Age (yrs), (X士S.D) } & \multicolumn{2}{|c|}{$\begin{array}{c}\text { Deceased group } \\
(\text { No }=74)\end{array}$} & \multicolumn{2}{|c|}{$\begin{array}{c}\text { Survival group } \\
(\text { No }=374)\end{array}$} & \multirow{2}{*}{$\begin{array}{c}\begin{array}{c}\mathbf{t} \\
\text { Value }\end{array} \\
2.947 \\
\end{array}$} & \multirow[t]{2}{*}{$\chi^{2}$} & \multirow{2}{*}{$\begin{array}{c}\mathbf{P} \\
\text { Value } \\
0.036^{*}\end{array}$} \\
\hline & 59.44 & 5.89 & 47.9 & 9.93 & & & \\
\hline $\begin{array}{ll}\text { Sex. } & \text { Male } \\
& \text { Female } \\
\end{array}$ & $\begin{array}{l}60 \\
14 \\
\end{array}$ & $\begin{array}{l}80.2 \% \\
17.8 \% \\
\end{array}$ & $\begin{array}{l}245 \\
129\end{array}$ & $\begin{array}{l}65.5 \% \\
34.5 \% \\
\end{array}$ & & 0.83 & $0.005 *$ \\
\hline $\begin{array}{c}\text { Smoker. } \begin{array}{c}\text { Smoker } \\
\text { Non-smoker }\end{array}\end{array}$ & $\begin{array}{l}12 \\
62 \\
\end{array}$ & $\begin{array}{l}16.4 \% \\
83.6 \%\end{array}$ & $\begin{array}{c}92 \\
282\end{array}$ & $\begin{array}{l}24.6 \% \\
75.4 \% \\
\end{array}$ & & 1.75 & 0.131 \\
\hline $\begin{array}{ll}\text { NSAIDS use } & \text { User. } \\
& \text { Non user }\end{array}$ & $\begin{array}{l}18 \\
56\end{array}$ & $\begin{array}{l}23.3 \% \\
76.7 \%\end{array}$ & $\begin{array}{l}126 \\
248\end{array}$ & $\begin{array}{l}22.4 \% \\
77.6 \%\end{array}$ & & 0.13 & 0.811 \\
\hline $\begin{array}{l}\text { Number of attacks } \\
\qquad 1^{\text {st. }} \text { attack } \\
2^{\text {nd. }} \text { attack } \\
\text { Recurrent }\end{array}$ & $\begin{array}{c}2 \\
22 \\
50\end{array}$ & $\begin{array}{l}2.7 \% \\
28.8 \% \\
68.5 \%\end{array}$ & $\begin{array}{c}84 \\
109 \\
181 \\
\end{array}$ & $\begin{array}{l}22.5 \% \\
29.1 \% \\
48.4 \%\end{array}$ & & 18.62 & $0.003 *$ \\
\hline $\begin{array}{ll}\text { Severity } & \text { Mild } \\
& \text { Moderate } \\
& \text { Severe } \\
\end{array}$ & $\begin{array}{c}2 \\
15 \\
57 \\
\end{array}$ & $\begin{array}{c}2.7 \% \\
19.2 \% \\
78.1 \% \\
\end{array}$ & $\begin{array}{c}132 \\
168 \\
74 \\
\end{array}$ & $\begin{array}{l}35.3 \% \\
44.9 \% \\
19.8 \% \\
\end{array}$ & & 0.98 & $0.004^{*}$ \\
\hline $\begin{array}{ll}\text { Child class } & \text { Class A } \\
& \text { Class B } \\
& \text { Class C } \\
\end{array}$ & $\begin{array}{c}0 \\
5 \\
69 \\
\end{array}$ & $\begin{array}{c}0 \\
5.5 \% \\
94.6 \% \\
\end{array}$ & $\begin{array}{c}22 \\
184 \\
168 \\
\end{array}$ & $\begin{array}{l}5.9 \% \\
49.2 \% \\
44.9 \% \\
\end{array}$ & & 10.79 & $0.029 *$ \\
\hline $\begin{array}{r}\text { Comorbidity: Diabetes } \\
\text { Heart failure } \\
\text { COPD } \\
\text { Renal Failure } \\
\end{array}$ & $\begin{array}{c}26 \\
5 \\
4 \\
16 \\
\end{array}$ & $\begin{array}{c}35.6 \% \\
6.8 \% \\
5.5 \% \\
17.8 \% \\
\end{array}$ & $\begin{array}{c}14 \\
6 \\
17 \\
6 \\
\end{array}$ & $\begin{array}{l}3.7 \% \\
1.6 \% \\
4.5 \% \\
1.6 \% \\
\end{array}$ & & 103.8 & $0.024^{*}$ \\
\hline $\begin{array}{ll}\text { Complications: } & \text { SBP } \\
& \text { HCC } \\
& \text { Ascites }\end{array}$ & $\begin{array}{l}28 \\
51 \\
69\end{array}$ & $\begin{array}{c}38.4 \% \\
69.9 \% \\
92 \%\end{array}$ & $\begin{array}{c}90 \\
30 \\
314\end{array}$ & $\begin{array}{c}24.1 \% \\
8 \% \\
84 \%\end{array}$ & & $\begin{array}{c}3.33 \\
18.29 \\
10.13\end{array}$ & $\begin{array}{l}0.026^{*} \\
0.039^{*} \\
0.056^{*}\end{array}$ \\
\hline $\begin{array}{c}\text { Bleeding during edoscopy } \\
\text { Bleeder } \\
\text { Non- bleeder }\end{array}$ & $\begin{array}{l}54 \\
20\end{array}$ & $\begin{array}{l}72.4 \% \\
27.6 \% \\
\end{array}$ & $\begin{array}{c}85 \\
289 \\
\end{array}$ & $\begin{array}{l}22.7 \% \\
77.3 \% \\
\end{array}$ & & 2.53 & $0.039 *$ \\
\hline $\begin{aligned} & \text { Endoscopy } \leq 8 \mathrm{hrs} \\
& 9-11 \mathrm{hrs} \\
& 12-23 \mathrm{hrs} \\
& 24-48 \mathrm{hrs} \\
&\end{aligned}$ & $\begin{array}{l}10 \\
14 \\
23 \\
27 \\
\end{array}$ & $\begin{array}{c}13.7 \% \\
17.8 \% \\
31.5 \% \\
37 \% \\
\end{array}$ & $\begin{array}{c}229 \\
71 \\
56 \\
18 \\
\end{array}$ & $\begin{array}{c}61.2 \% \\
19 \% \\
15 \% \\
4.8 \% \\
\end{array}$ & & 9.23 & $0.031 *$ \\
\hline $\begin{array}{r}\text { Vasopressor use: } \text { Used } \\
\text { Not used }\end{array}$ & $\begin{array}{l}15 \\
59 \\
\end{array}$ & $\begin{array}{l}19.2 \% \\
80.8 \% \\
\end{array}$ & $\begin{array}{c}92 \\
281 \\
\end{array}$ & $\begin{array}{l}24.6 \% \\
75.1 \% \\
\end{array}$ & & 1.63 & 0.54 \\
\hline $\begin{array}{ll}\text { Endoscopy } & \text { Grade } 2 \mathrm{OV} \\
& \text { Grade } 3 \mathrm{OV} \\
& \text { GOV } \\
& \text { Isolated GV } \\
\end{array}$ & $\begin{array}{c}5 \\
34 \\
14 \\
20 \\
\end{array}$ & $\begin{array}{l}6.8 \% \\
46.6 \% \\
19.2 \% \\
27.4 \% \\
\end{array}$ & $\begin{array}{c}147 \\
121 \\
66 \\
38 \\
\end{array}$ & $\begin{array}{l}39 \% \\
32 \% \\
17 \% \\
10 \% \\
\end{array}$ & & 27.42 & $0.042 *$ \\
\hline APACHE II & 26.75 & 3.68 & 16.98 & 3.39 & 27.46 & & $0.003 *$ \\
\hline Meld score. & 29.3 & 6.98 & 13.44 & 5.24 & 18.42 & & $0.004 *$ \\
\hline Alaninetransferase(ALT) & 51.6 & 19.43 & 47.16 & 16.5 & 1.81 & & $0.047 *$ \\
\hline Platelets count. & 77.71 & 39.18 & 131.52 & 71.97 & 10.85 & & $0.036^{*}$ \\
\hline Creatinine. & 4.88 & 3.92 & 2.07 & 1.02 & 4.68 & & $0.035 *$ \\
\hline Urea level & 121 & 19 & 52 & 38 & 36.8 & & $0.039 *$ \\
\hline Bilirubin & 8.02 & 5.9 & 2.48 & 4.94 & 6.65 & & $0.027 *$ \\
\hline INR & 7.89 & 3.28 & 3.22 & 1.62 & 4.8 & & $0.014^{*}$ \\
\hline
\end{tabular}

$(\chi 2)=$ chi-square value, $(t-V a l u e)=$ independent $t$-test value, $(p$ value $)=$ significance value when $(p-$ value) $<0.05=$ significant difference, $(p$ value $)<0.01=$ highly significant difference, $(p-v a l u e)>0.05=$ no significant difference. 
Table (2): Univariate analysis of the data of the deceased group compared to survived group: Higher age, male sex, increasing number of bleeding attack, increasing severity of the attack, association with higher child class of liver disease, presence of other co-morbidity, or other cirrhotic complications, delayed endoscopic intervention, increased grade of esophageal varices, presence of gastric varices, higher child-pough, APACHE II, MELD scores and low platelets count are predictors of mortality.

Table (3): Backword stepwise regression analysis of the factor predicting survival among study group.

\begin{tabular}{|l|c|c|c|c|}
\hline \multicolumn{1}{|c|}{ Variable } & B value & St. Er & WALD & Sig. \\
\hline APACHE II & 3.50 & 1.63 & 4.16 & $0.023^{*}$ \\
\hline MELD SCORE & 1.35 & 0.04 & 12.97 & $0.034^{*}$ \\
\hline Severity of the attacks & 2.54 & 3.66 & 5.24 & $0.036^{*}$ \\
\hline Time to endoscopy & 2.25 & 0.13 & 3.75 & $0.041^{*}$ \\
\hline ALT & 1.89 & 0.09 & 3.91 & $0.042^{*}$ \\
\hline AGE & 1.76 & 0.12 & 3.79 & $0.046^{*}$ \\
\hline SBP & 1.55 & 0.05 & 2.47 & $0.049^{*}$ \\
\hline SEX & 3.25 & 775 & 0.00 & 1 \\
\hline Sr. creatinine & 7.78 & 993 & 0.00 & 1 \\
\hline INR & 0.14 & 29.62 & 0.00 & 1 \\
\hline PLAT. NO & 0.04 & 10.23 & 0.00 & 1 \\
\hline Constant. & -28.2 & 6.39 & 19.56 & ------ \\
\hline
\end{tabular}

$*=\mathbf{P}$ is significant

Table (3): Backword stepwise regression analysis of the factor predicting survival among study group: The APACHE II score ( $p=0.023)$ and MELD SCORE $(p=0.034)$, severity of the attacks $(p=0.036)$, time to Endoscopy $(\mathrm{p}=0.041)$, ALT level $(\mathrm{p}=0.042)$, advancing Age $(\mathrm{p}=0.046)$, presence of Comorbidities $(\mathrm{p}=0.048)$ and occurrence of spontaneous bacterial peritonitis $(\mathrm{SBP})(\mathrm{p}=0.049)$ are independent risk factors for mortality in patients with bleeding varices.

\section{DISCUSSION}

High mortality rates have been reported in older literature for patients with acute variceal bleeding although there was a trend towards improved survival in recent years [13].

In our study we estimated the prevalence of upper gastrointestinal bleeding (UGIB) in medical ICU within the period from May to September 2013 and it was $13.7 \%$ of all cases admitted to medical ICU and $61 \%$ of patients admitted with UGIB in that period, $84.4 \%$ of them known previously to suffer from chronic liver disease(CLD), and the rest $(15.6 \%)$ were diagnosed to be hepatic for the first time. The relatively high rate of variceal UGIB in our country may be attributed to high prevalence of chronic virus $\mathrm{C}$ hepatitis and bilharzial periportal fibrosis [14].

The high prevalence of variceal UGIB is considered one of the most serious health problems affecting our patients and a serious burden on our hospitals.
The reported prevalence of esophageal varices in patient with chronic liver disease (CLD) is variable. Schepis et al. [15], in a comprehensive review, gave figures ranging between $24 \%$ and $80 \%$, with a mean of about $60 \%$. The prevalence of varices appears to be related to the degree of liver dysfunction. D'Amico et al. [16] found that the prevalence was $30 \%$ for compensated CLD patients and $60 \%$ for decompensated CLD patients. This was further supported by data from Primignani et al. [8] who revealed, in a population of compensated CLD (88\% Child Class A, 12\% Child Class B) patients, that the prevalence of varices was $16 \%$. This low prevalence compared to our values may be due to the high percentage of class A patients in this study. Because of this variability, and because of the relative inaccuracy of non-invasive tests, it has been recommended that all patients with cirrhosis should be evaluated by endoscopy to ascertain the presence of portal hypertension [17]. 
We tried to demonstrate the relationship between early in-hospital mortality and many factors and to calculate the risk of their presence in the involved patients.

Our results showed that the mortality rate of variceal bleeding (VB) was $16.5 \%$. Alserag and Everhart [18] reported that variceal bleeding mortality was $14.5 \%$. Kind et al. [19] reported that mortality of VB was $19.5 \%$. In another study done by Lewis et al. [20] the mortality of VB ranged from 28 to $63 \%$. Early mortality was $20 \%$ in a study done by Carbonell et al. [21].

The decreasing mortality in patients with variceal bleeding can be explained by the early endoscopic intervention, better resuscitation and better management of comorbid conditions.

In this study, there was a significant positive correlation between hospital mortality and the age of the patients. Age is also a predictor of death identified in studies done by Sempere et al. [22] and D'Amico et al. [23]. The age related mortality is probably related to the presence of three factors in the older population: a longer duration of liver disease, a greater chance to have associated comorbidities, and the difficulty of liver transplantation in the elderly.

In our study, sex had an impact on mortality. The incidence of mortality in male sex was more than female sex ( $80 \%$ vs $18 \%$ respectively). Male sex, according to Gines et al. [24] indicated poorer prognosis in cirrhotic patients, independent of the stage of the underlying liver disease, age or co-morbidity. Rockall et al. [1] clarified the positive correlation between mortality and each of the patient's age and male sex

Our study also revealed that there was significant positive correlation between mortality and Child-Pugh score. The risk of mortality increased when going from (A) to (C). This was in agreement with Patch and Dagher [25] and D'Amico et al. [26] who showed that 6 weeks mortality seemed to be more related to the stage of the liver disease than to any other factors. Also, Garcia-Taso et al. [27], stated that the stage of liver disease is the most important factor contributing to mortality in intensive care unit patients suffering from upper GIT bleeding.

We found that the mean Child-Pugh score in deceased patients was $(11.95 \pm 1.12)$, which was higher than survived patients' mean score $(9.43 \pm$ 2.24),
Our results revealed that co-morbid conditions (diabetes, COPD, renal failure and heart failure) were found in $20.3 \%$ of our patients and their presence increased the mortality compared to those who had not any comorbidity. This fact was proved by Marmo et al. [28] who had suggested that chronic comorbidities played a critical role in predicting health-care outcomes and mortality in variceal upper GIT bleeding.

In accordance with our results, Afessa et al. [29] had concluded that renal disease and coagulopathy constituted risk factors in their study. In a similar study, Blatchford et al. [11] demonstrated that renal failure and liver failure had been reported as a risk factors variceal rebleeding and mortality.

In this study, the presence of SBP and HCC, were independent predictors of mortality in the patients with variceal UGIB in agreement with Loomba, et al. [30].

Our results proved that the severity of bleeding episode was significantly positively correlated with the mortality. This was in agreement with a study conducted by Rockall et al. [1], who found that hemorrhage that needed surgery and rebleeding were associated with a higher risk of death.

This work confirmed that early resuscitation and early endoscopy significantly reduced the risk of mortality. This was in agreement with Bosch et al. [3] and Garcia-Tsao et al. [27] who recommend that endoscopic intervention must be

performed within $12 \mathrm{~h}$ of admission in patients with acute VB to improve survival.

In agreement with previous results by Pompili et al. [31] we found that the mean \pm S.D of ALT level in survived group (47.16 \pm 16.5$)$ was lower than that of the deceased group $(51.6 \pm 19.43)$. The elevation of the ALT level at the time of acute variceal bleeding indicated an ongoing liver injury, possibly leading to deterioration of the functional hepatic mass and therefore, predicting subsequent mortality. D'Amico et al. [23] reported that the impact of ALT level on the prognosis of variceal hemorrhage is controversial.

The MELD score, initially developed to assess prognosis following TIPS placement, is now accepted as a useful prognostic model for patients with advanced cirrhosis [32]. 
Our study showed significant increase of bilirubin, creatinine, international normalizing ratio (INR) of the deceased group than the survived groups, As included in MELD score the serum Creatinine level, Bilirubin and INR. markedly affect the mortality in accordance to Malinchoc et al. [10].

The mean \pm S.D of MELD score in deceased patients was higher compared to survived patients $(29.3 \pm 6.98$ vs $13.4 \pm 5.24)$. This means that when the MELD score is high, more mortality is expected. These results was concordant with that found by Amitrano et al. [33] who stated that a high MELD score is a predictor of early in-hospital mortality in patients with cirrhosis and variceal hemorrhage.

Our results were in agreement with the study of Fernández-Esparrach et al. [34] who stated that the MELD score is better prognostic indicator as it allows the assessment of renal dysfunction.

We demonstrated that low level of hemoglobin as well as blood pressure and the need for red blood cell transfusion were identified as risk factors for death in upper GI bleeding. This was in accordance with Blatchford et al. [11].

In this work high APACHE II score was associated with marked increase in the risk of the mortality. There was no great difference between our results and Butt et al. [35] who reported that mean \pm S.D of APACHE II score for deceased and survivors $(26.7 \pm 6.38),(16.9 \pm 3.39)$ respectively .

The regression analysis of our patients data demonstrated that the APACHE II score, MELD scale, severity of the attacks, time to endoscopy, ALT level, advanced age, comorbidities and SBP were the most independent factors affecting the early mortality of patients admitted with variceal UGIB.

The limitation of the study included lacking of long term follow up of these patients after discharge from medical ICU, missing of comment on other confounding factors like use of antibiotics during ICU stay and verification of the role of other important comorbidities like association with schistosomasis and Helicobacter pylori.

\section{RECOMMENDATION}

Being a great problem in our health care system, bleeding esophageal varices require a well formulated protocols for primary and secondary prevention as well as better adherence to current guidelines for management of such cases to minimize the mortality as much as possible. long term follow up studies are required to identify the significantly important prognostic factors.

\section{Funding:Non.}

\section{Conflict of interest: Non.}

Ethical approval:The styudy was approved by The Ethical Committee of Faculty of Medicine, Zagazig University. After being informed on the purpose and procedures of the study, all subjects or their relatives singed an informed consent form to participate in the study.

\section{REFERENCES}

1. Rockall TA, Logan RFA, Devlin HB Northfield TC. Steering committee and members of the National Audit of Acute Upper Gastrointestinal Hemorrhage. Risk assessment after acute upper gastrointestinal haemorrhage. Gut 1996;38:31621.

2. McCormick PA, and O'Keefe C. Improving prognosis following a first variceal haemorrhage over four decades. Gut 2001; 49:682-5.

3. Bosch J, and Garcia-Pagan J. Prevention of variceal rebleeding. Lancet 2003; 9361:952-4.

4. Chalasani N, Kahi C, Francois F, Pinto A, Marathe A, Bini EJ et al. Model for end-stage liver disease (MELD) for predicting mortality in patients with acute variceal bleeding. Hepatology 2002; 35: 1282-1284.

5. Abraldes J G, Dell'Era A, Bosch J. Medical management of variceal bleeding in patients with cirrhosis. Can J Gastroenterol.2004; 18(2): 109113.

6. Cuellar RE, Gavaler JS, Alexander JA, Brouillette DE, Chien MC, Yoo YK et al. "Gastrointestinal tract hemorrhage. The value of a nasogastric aspirate". Arch. Intern. Med.1990; 150 (7): 1381-4.

7. Primignani M, Albe R, Preatoni P, Carnevale P, Bianchi MB, Parravicini E, et al. 'De nova' development of esophageal varices in patients with a recent histologic diagnosis of liver cirrhosis. Gastroenterology 1998; 114:A1324. 
8. Merli M, Nicolini G, Angeloni S, Rinaldi V, De Santis A, Merkel C et al. Incidence and natural history of small esophageal varices in cirrhoticpatients. J Hepatol 2003.; 38: 266-72.

9. Groszmann RJ, Garcia-Tsao G, Bosch J, Grace ND, Burroughs AK, Planas $\mathrm{R}$ et al. Betablockers to prevent gastro-esophageal varices in patients with cirrhosis. N Engl J Med.2005; 353: 2254-61.

10. Malinchoc M, Kamath PS, Gordon FD, Peine CJ, Rank J, ter Borg PC. A model to predict poor survival in patients undergoing transjugular intrahepatic portosystemic shunts. Hepatology 2000; 31:864-71.

11. Blatchford O, Murray WR, Blatchford M. A risk score to predict need for treatment for uppergastrointestinal haemorrhage. Lancet 2000;356: 1318-1321

12. Knaus WA, Wagner DP, Draper EA, Zimmerman JE, Bergner M, Bastos PG et al.The APACHE III prognostic system. Risk prediction of hospital mortality for critically ill hospitalized adults Chest 1991; 100:1619-1636.

13. McCormick PA, O'Keefe C. Improving prognosis following a first variceal haemorrhage over four decades. Gut2001; 49:682-5.

14. Bellis MA, Hughes K, Morleo M, Tocque K, Hughes S, Allen T et al. Predictors of risky alcohol consumption in schoolchildren and their implications for preventing alcohol-related harm. Subst Abuse Treat Prev Policy 2007; 2: 15.

15. Schepis F, Cammà C, Niceforo D, Magnano A, Pallio S,Cinquegrani $M$ et al . Which patients with cirrhosis should undergo endoscopic screening for oesophageal varices detection? Hepatology 2001 ;33:333-338.

16. D’Amico G, Luca A. Natural history.Clinicalhaemodynamic correlations. Prediction of the risk of bleeding. BaillieresClin Gastroenterol. 1997; 11: 243-56.

17. Garcia-Tsao G, Sanyal AJ, Grace ND, Carey WD. Prevention and management of gastroesophageal varices and variceal hemorrhage in cirrhosis. Am J Gastroenterol 2007.; 102: 2086-102.

18. Alserag HB, Everhart JE, Improved survival after variceal bleeding over an 11 year period in the Departmen of Veterans Affairs. Am J Gasroenterol 2000; 95: 3566-3573.

19. Kind R, Guglielmi A, Rodella L, Lombardo F, Catalano F, Ruzzenente A et al,. Bucrylate treatment of bleeding gastric varices: 12 years' experience. Endoscopy 2000; 32: 512-9.
20. Lewis JD, Shin EJ, Metz DC . Characterization of gastrointestinal bleeding in severely hospitalized patients. Crit Care Med.2000; 28:46-50

21. Carbonell N, Pauwels A, Serfaty L, Fourdan O, Lévy VG, Poupon R. et al. Improved survival after variceal bleeding in patients with cirrhosis over the past two decades. Hepatology 2004; 40(3):652-659.

22. Sempere L, Palazón JM, Sánchez-Payá J, Pascual S, de Madaria E, Poveda MJ, et al . Assessing the short and long-term prognosis of patients with cirrhosis andacute variceal bleeding. Rev Esp Enferm Dig. 2009 ; 101: 236-48.

23. D’Amico G, Garcia-Tsao G, Pagliaro L. Natural history and prognostic indicators of survival in cirrhosis: asystematic review of 118 studies. $J$ Hepatol.2006; 44: 217-31.

24. Gines P, Quintero E, Arroyo V, Terés J, Bruguera M, Rimola A et al. Compensated cirrhosis: natural history and prognostic factors. Hepatology 1987; 7:122-8.

25. Patch D, Dagher L. Acute variceal bleeding: general management. World $J$ Gastroenterol 2001.; 7(4):466-75.

26. D'Amico G, De Franchis R. Upper digestive bleeding in cirrhosis. Post-therapeutic outcome and prognostic indicators. Hepatology 2003; 38:599-612.

27. Garcia-Tsao G, Bosch J, Groszmann RJ. Portal hypertension and variceal bleeding-unresolved issues. Summary of an American Association for the study of liver diseases and European Association for the study of the liver single-topic conference. Hepatology 2008; 47:1764-72.

28. Marmo R, Koch M, Cipolletta L, Capurso L, Pera A, Bianco MA et al. Predictive factors of mortality from non-variceal upper gastrointestinal hemorrhage: a multicentre study. Am J Gastroenterol 2008;103:1639-47.

29. Afessa B. and Kubilis PS .Upper gastrointestinal bleeding in patients with hepaticcirrhosis: clinical course and mortality prediction. Am J Gastroenterol 2000.; 95:484-489.

30. Loomba R, Wesley R, Bain A, Csako G, Pucino F. Role of fluoroquinolones in the primary prophylaxis of spontaneous bacterial peritonitis: meta-analysis. Clin Gastroenterol Hepatol. 2009; 7:487-493.

31. Pompili M, Rapaccini GL, Covino M, Pignataro G, Caturelli E, Siena DA et al. Prognostic factors for survival in patients with compensated cirrhosis and small hepatocellular carcinoma after percutaneous ethanol injection therapy. Cancer 2001; 92:126-35. 
32. Kamath PS, Wiesner RH, Malinchoc M, Kremers W, Therneau TM, Kisberg CL et al. A model to predict survival in patients with end stage liver disease. Hepatology 2001; 33:464-470.

33. Amitrano L, Guardascione MA, Bennato R, Manguso F, Balzano A. MELD score and hepatocellular carcinoma identify patients at different risk of short-term mortality among cirrhotics bleeding from esophageal varices. $J$ Hepatol. 2005; 42:820-5.

34. Fernández-Esparrach G, Sánchez-Fueyo A, Gines P, Uriz J, Quinto L, Ventura PJ, et al. A prognostic model for predicting survival in cirrhosis with ascites. J Hepatol 2001; 34: 46-52.
35. Butt AK, Khan AA, Alam A, Shah SWH, Shafqat F, and Naqvi AB. Predicting hospital mortality in cirrhotic patients: Comparison of Child-Pugh and Acute Physiology, Age and Chronic Health Evaluation (APACHE II) scoring systems Am J Gastroenterol.1998; 93:2469-2475).

Peer reviewer :Sahar Zaglol; Professor of Internal Medicine, Faculty of Medicine , Zagazig University, Egypt.Editor:Tarik Zaher; Professor of Tropical Medicine, Faculty of Medicine , Zagazig University, Egypt. 